\title{
Properties of dissolved and total organic matter in throughfall, stemflow and forest floor leachate of central European forests
}

\author{
S. Bischoff ${ }^{1}$, M. T. Schwarz ${ }^{2}$, J. Siemens ${ }^{3}$, L. Thieme ${ }^{3}$, W. Wilcke ${ }^{2, *}$, and B. Michalzik ${ }^{1}$ \\ ${ }^{1}$ Institute of Geography, Friedrich Schiller University Jena, Löbdergraben 32, 07743 Jena, Germany \\ ${ }^{2}$ Institute of Geography, University of Berne, Hallerstrasse 12, 3012 Berne, Switzerland \\ ${ }^{3}$ Institute for Crop Science and Resource Conservation, Rheinische Friedrich Willhelms University Bonn, \\ Nussallee 13, 53115 Bonn, Germany \\ *now at: Institute of Geography and Geoecology, Karlsruhe Institute of Technology, Reinhard-Baumeister-Platz 1, \\ 76131 Karlsruhe, Germany
}

Correspondence to: S. Bischoff (sebastian.bischoff@uni-jena.de)

Received: 15 September 2014 - Published in Biogeosciences Discuss.: 24 October 2014

Revised: 2 April 2015 - Accepted: 9 April 2015 - Published: 7 May 2015

\begin{abstract}
We present the first investigation of the composition of dissolved organic matter (DOM) compared to total organic matter (TOM, consisting of DOM, $<0.45 \mu \mathrm{m}$ and particulate organic matter $0.45 \mu \mathrm{m}<\mathrm{POM}<500 \mu \mathrm{m}$ ) in throughfall, stemflow and forest floor leachate of common beech (Fagus sylvatica L.) and Norway spruce (Picea abies (L.) H. Karst.) forests using solid-state ${ }^{13} \mathrm{C}$ nuclear magnetic resonance (NMR) spectroscopy. We hypothesized that the composition and properties of organic matter $(\mathrm{OM})$ in forest ecosystem water samples differ between DOM and TOM and between the two tree species.

The ${ }^{13} \mathrm{C}$ NMR results, derived from 21 samples, point to pronounced differences in the composition of DOM and TOM in throughfall solution at the beech sites, with TOM exhibiting higher relative intensities for the alkyl $\mathrm{C}$ region, which represents aliphatic $\mathrm{C}$ from less decomposed organic material compared to DOM. Furthermore, TOM shows lower intensities for lignin-derived and aromatic $\mathrm{C}$ of the aryl $\mathrm{C}$ region resulting in lower aromaticity indices and a diminished degree of humification. Across the ecosystem compartments, differences in the structural composition of DOM and TOM under beech lessened in the following order: throughfall > stemflow $\approx$ forest floor leachate.

In contrast to the broadleaved sites, differences between DOM and TOM in throughfall solution under spruce were less pronounced and spectra were, overall, dominated by the alkyl $\mathrm{C}$ region, representing aliphatic $\mathrm{C}$. Explanations of the reported results might be substantiated in differences in tree
\end{abstract}

species-specific structural effects, leaching characteristics or differences in the microbial community of the tree species' phyllosphere and cortisphere. However, the fact that throughfall DOM under beech showed the highest intensities of recalcitrant aromatic and phenolic $\mathrm{C}$ among all samples analysed likely points to a high allelopathic potential of beech trees negatively affecting other organisms and hence ecosystem processes and functions.

\section{Introduction}

Dissolved organic matter (DOM), often described as the solutes that can pass through a filter with $<0.45 \mu \mathrm{m}$ pore size, contributes substantially to the biogeochemistry of carbon (C) and nitrogen (N) in forest ecosystems (Qualls et al., 1991; Michalzik and Matzner, 1999; Fröberg et al., 2006; Kindler et al., 2011). While many investigations have addressed the nature and dynamics of DOM in terrestrial ecosystems (e.g. Qualls and Haines, 1991; Currie et al., 1996), only a few have investigated the dynamics (Carlisle et al., 1966; Sollins et al., 1980; le Mellec et al., 2009, 2010) and none the character of water-bound total OM (TOM) including the particulate organic matter fraction (POM; $0.45 \mu \mathrm{m}<\mathrm{POM}<$ $500 \mu \mathrm{m})$. Since water-bound element and nutrient concentrations are conventionally measured after filtration (frequently to $<0.45 \mu \mathrm{m}$ pore size), the exclusion of the POM frac- 
tion potentially results in misleading inferences and budgeting gaps in studies of nutrient and energy fluxes in ecosystems (Michalzik and Stadler, 2005; Stadler et al., 2006). We are aware of only a handful of studies over the last 35 years which address POM or size equivalents in temperate broadleaved and coniferous ecosystems (e.g. Carlisle et al., 1966; Sollins et al., 1980; Likens et al., 1983; Lamersdorf and Blank, 1995; Levia et al., 2013). The majority of these studies highlighted the importance of organic matter (OM) $>0.45 \mu \mathrm{m}$ to the overall budgets of $\mathrm{C}, \mathrm{N}$ and other nutrients. Lamersdorf and Blank (1995) revealed a significant additional input of organic carbon and nitrogen to the soil with throughfall (TF) via the particulate fraction $(>0.45 \mu \mathrm{m})$. These results are corroborated by recent findings for POM and DOM in the TF of beech, spruce and pine forest stands (le Mellec and Michalzik, 2008; le Mellec et al., 2009, 2010), where the additional input of $\mathrm{C}$ and $\mathrm{N}$ by particulate organic matter represented between 20 and $30 \%$ of the total organic $\mathrm{C}$ and $10-20 \%$ of the total $\mathrm{N}$ fluxes with throughfall. The low C-to-N ratios of 12-14 for POM as reported by Lamersdorf and Blank (1995) furthermore suggest that this material might be particularly relevant in promoting microbial decomposition processes (Fontaine et al., 2004), while wider Cto- $\mathrm{N}$ ratios of $>30$ tend to decelerate decomposition rates (Pérez-Harguindeguy et al., 2000).

Although some knowledge of the amount and temporal dynamics of DOM and POM is available, the composition especially of TOM in solutions and its alteration as it traverses forest canopies, stem surfaces and subsequently the forest floor (FF) is largely unknown. The chemical nature of mobile $\mathrm{OM}$ is a prerequisite for advancing our understanding of the $\mathrm{C}$ and nutrient cycling as well as other ecosystem processes in forests (Schnitzer and Khan, 1972; Guggenberger and Zech, 1994; Wardle et al., 1998). Alteration in the composition of OM in throughfall, stemflow (SF) and FF solutions are assumed to be driven by various abiotic and biotic processes. In this context, precipitation patterns (Mercier and Lindow, 2000) and canopy architecture (Levia and Frost, 2006; Levia et al., 2012) basically alter the release of OM with throughfall. Atmospheric deposition (e.g. pollen, inorganic $\mathrm{N}$ deposition; Lamersdorf and Blank, 1995) and increased nutrient leaching from damaged leaves and immobilization processes within the canopy mediated by phyllosphere microorganisms (Guggenberger and Zech, 1994; Stadler and Müller, 2000) appear to influence the chemical qualities of OM from the forest canopy. Interspecific differences in bark traits and cortisphere properties, e.g. bark texture and colour, influence the microclimate and arthropod fauna (Nicolai, 1986), the plant epiphyte (Wyse and Burns, 2011) and microbial community (Andrews and Harris, 2000) consequently affecting the amount and composition of OM as well. For example, enhanced bark microrelief increases the contact time of stemflow solutions with bark surfaces leading to an enrichment of aromatic hydrocarbons (Levia et al., 2012) likely due to the enhanced degradation and release of soluble lignin compounds (Guggenberger et al., 1994).

Previous work has demonstrated that tree species and spatial and temporal patterns of environmental conditions such as chemical soil properties influence the input and cycling of cations (Gersper and Holowaychuk, 1971; Finzi et al., 1998; Levia et al., 2011; Van Stan et al., 2012) and DOM in temperate forests (Levia et al., 2012). However, it is unclear how tree species influence the chemical properties of DOM and especially of POM in TF, SF and FF leachates and hence how they subsequently affect soil processes by varying chemical compositions and associated functionalities. In this context, beech trees potentially exhibit the highest amounts of phenolics in leaves (Bussotti et al., 1998), bark (Dübeler et al., 1997), wood (Mämmelä, 2001) and roots (Weissen and Van Praag, 1991) compared to co-occurring species. Phenolic compounds released from living or dead plant material have been shown to function as allelochemicals, affecting associated species (Rice, 1984; Wardle et al., 1998). An interspecific allelopathic potential on other organisms may result in net changes in ecosystem processes and functions (e.g. herbivory, decomposition and nutrient mineralization; Wardle et al., 1998). However, the release of phenolic or other allelopathic compounds from living plant material via throughfall and stemflow and the effects on ecosystem processes and function are still insufficiently understood.

To elucidate the composition of DOM and TOM in terrestrial ecosystem water samples we applied solid-state ${ }^{13} \mathrm{C}$ nuclear magnetic resonance spectroscopy with crosspolarization and magic-angle spinning (CPMAS-NMR), which is a nondestructive method that provides information on the chemical surroundings of $\mathrm{C}$ atoms forming the major component of OM. Consequently, solid-state ${ }^{13} \mathrm{C}$ NMR spectroscopy is widely used for the characterization of a range of organic materials from various natural environments (Baldock et al., 2004). It has been applied to soil OM (Helfrich et al., 2006; Keeler et al., 2006), hot water extracts (Leinweber et al., 1995; Balaria et al., 2009) and DOM in aqueous solutions from aquatic (Schumacher et al., 2006) and terrestrial ecosystems (Guggenberger et al., 1994; Fröberg et al., 2003; Sanderman et al., 2008). Although the technique has been applied to POM from aquatic systems (McKnight et al., 1997; Lankes et al., 2008), to the best of our knowledge, it has never been applied to POM or TOM in aqueous samples from terrestrial ecosystems such as TF, SF or FF leachates. Therefore, we present the first study investigating the composition of DOM compared to TOM by solid-state ${ }^{13} \mathrm{C}$ NMR spectroscopy.

We tested the hypotheses that the structural composition of DOM in filtered and TOM in unfiltered forest ecosystem water samples differs (i) across ecosystem compartments and (ii) between tree species, using the test case of differences between beech and spruce in one of our study regions. 


\section{Methods}

\subsection{Study sites}

The sites are in three landscapes forming part of the German "Biodiversity Exploratories" (www.biodiversity-exploratories.de), which were established in 2006 as a scientific platform for biodiversity research funded by the German Research Foundation (DFG SPP 1374 "Exploratories for Large-scale and Long-term Functional Biodiversity Research"; see Fischer et al. (2010) for a detailed description). The three regions differ in environmental conditions (Table 1) and are representative of large areas of Central Europe. We selected three extensively managed "close-to-native" European beech forests (Fagus sylvatica L.; mature forest stands, protected for at least 60 years; see Fischer et al., 2010) in each of the three "exploratories". These forests are comparable with regard to tree age and tree species composition and are similar in stand density, mean tree diameter at breast height, basal area and forest management (Table 2). In the Hainich-Dün exploratory (HAI), we additionally collected samples from three Norway spruce (Picea abies (L.) H. Karst.) plantations (Table 2). We choose the HAI spruce sites because the Schorfheide-Chorin ( $\mathrm{SCH}$ ) exploratory only provides pine (Pinus sylvestris L.) stands and the spruce stands of the Schwäbische Alb exploratory (ALB) differ in tree species composition (Schwarz et al., 2014).

\subsection{Experimental set-up}

The experimental set-up was identical for all the sites. At each exploratory, bulk precipitation (BP) was collected in five replicates from three open areas using $2 \mathrm{~L}$ polyethylene (PE) open funnel samplers (diameter $0.12 \mathrm{~m}$ ). TF was sampled using rain collectors of the same type arranged in a cross-shaped grid, with 20 replicates per forest site. The sampling bottles were wrapped with aluminium foil to minimize the impact of irradiation and algal growth and were equipped with a polyester net (mesh width $1.6 \mathrm{~mm}$ ) to prevent sample contamination with coarse matter. Stemflow was collected in three replicates per site using sliced polyurethane hoses (diameter $4 \mathrm{~cm}$ ) as a collar installed at $1.60 \mathrm{~m}$ height, sealed with polyurethane glue, and connected with a polypropylene or PE barrel via a PE tube. To address the element input from the organic layer to the mineral soil, FF leachates were collected with three zero-tension lysimeters per site $\left(280 \mathrm{~cm}^{2}\right.$ sampling area), installed in the vicinity of the TF samplers. They consisted of polyvinyl chloride plates covered with a PE net (mesh width $0.5 \mathrm{~mm}$ ) connected with PE hoses to $2 \mathrm{~L}$ PE bottles stored in a box below ground.

\subsection{Sampling procedure and analysis}

Samples of BP, TF, SF and FF leachate were collected in September 2010 for ALB and the HAI beech sites and in
August and September 2011 for SCH and the HAI spruce sites after a biweekly routine sample collection interval. The reasons to choose these sampling dates were threefold: beech canopies were fully developed, external interfering events such as the release of pollen by coniferous trees (mid-May to mid-June) were over and, generally, sufficient water precipitation occurs during this time of the year, necessary to collect large amounts of sample solutions to perform the freeze-drying for solid-state ${ }^{13} \mathrm{C}$ NMR analysis. Individual samples of BP $(3$ sites $\times 5$ replicates $=15)$, $\mathrm{TF}(3$ sites $\times 20$ replicates $=60), \mathrm{SF}(3$ sites $\times 3$ replicates $=9)$ and FF leachates ( 3 sites $\times 3$ replicates $=9)$ were pooled to one volume-weighted sample per sample type, sampling date and exploratory. The samples were stored on ice in cool boxes until further processing in the laboratory. At the latest $24 \mathrm{~h}$ after collection, an aliquot of the BP, TF, SF and FF leachate samples was bottled unfiltered, whereas another was filtered with $<0.45 \mu \mathrm{m}$ cellulose acetate filters (Sartorius, Göttingen, Germany). Both the unfiltered and filtered aliquots were immediately frozen to prevent microbial alteration.

For solid-state ${ }^{13} \mathrm{C}$ NMR analysis, between 400 and $800 \mathrm{~mL}$ of the filtered and unfiltered sample aliquots were freeze-dried (Christ Alpha 1-4, Osterode/Harz, Germany). Samples of BP contained insufficient amounts $(<30 \mathrm{mg})$ of dry matter and could therefore not be analysed with NMR spectroscopy. The same held true for three other ALB samples, encompassing the filtered TF sample and the filtered and unfiltered SF samples. In total, 21 samples were analysed by solid-state ${ }^{13} \mathrm{C}$ NMR spectroscopy. Table 3 provides an overview of the sample consortium.

Solid-state ${ }^{13} \mathrm{C}$ NMR measurements were obtained with a Bruker DSX 200 NMR spectrometer (Bruker, Karlsruhe, Germany). CPMAS was applied with a ${ }^{13} \mathrm{C}$ resonance frequency of $50.32 \mathrm{MHz}$ and a spinning speed of $6.8 \mathrm{kHz}$. A ramped ${ }^{1} \mathrm{H}$ pulse starting at $100 \%$ and decreasing to $50 \%$ of the initial power was used during a contact time of $1 \mathrm{~ms}$ in order to circumvent spin modulation during the HartmannHahn contact. Pulse delays of $2 \mathrm{~s}$ were used for all spectra. Pre-experiments confirmed that the pulse delays were long enough to avoid saturation. Depending on the C content of the samples, 2070 to 130939 scans were accumulated and a line broadening between 50 and $100 \mathrm{~Hz}$ was applied. The ${ }^{13} \mathrm{C}$ chemical shifts were calibrated relative to tetramethylsilane $(0 \mathrm{ppm})$. Relative contributions from the various $\mathrm{C}$ groups were determined by integrating the signal intensity within their respective chemical shift regions according to Knicker et al. (2005). The region from 220 to $160 \mathrm{ppm}$ was assigned to carbonyl (aldehyde and ketone) and carboxyl/amide $\mathrm{C}$. Olefinic and aromatic $\mathrm{C}$ were detected between 160 and $110 \mathrm{ppm}$. O-alkyl and $\mathrm{N}$-alkyl C signals were found from 110 to $60 \mathrm{ppm}$ and from 60 to $45 \mathrm{ppm}$, respectively. Resonances of alkyl $\mathrm{C}$ were assigned to the region 45 to $-10 \mathrm{ppm}$. We calculated the alkyl C / O-alkyl C (A / OA) ratio for each fraction according to Baldock et al. (1997) 
Table 1. Environmental properties of the study regions (mainly given by Fischer et al., 2010; soil classification according to IUSS Working group WRB, 2006).

\begin{tabular}{|c|c|c|c|}
\hline & $\begin{array}{l}\text { Schorfheide-Chorin } \\
(\mathrm{SCH})\end{array}$ & $\begin{array}{l}\text { Hainich-Dün } \\
\text { (HAI) }\end{array}$ & $\begin{array}{l}\text { Schwäbische Alb } \\
\text { (ALB) }\end{array}$ \\
\hline Location & $\begin{array}{l}\text { Northeast Germany } \\
\left(53^{\circ} 2^{\prime} \mathrm{N}, 13^{\circ} 51^{\prime} \mathrm{E}\right)\end{array}$ & $\begin{array}{l}\text { Central Germany } \\
\left(51^{\circ} 10^{\prime} \mathrm{N}, 10^{\circ} 23^{\prime} \mathrm{E}\right)\end{array}$ & $\begin{array}{l}\text { Southwest Germany } \\
\left(38^{\circ} 24^{\prime} \mathrm{N}, 9^{\circ} 24^{\prime} \mathrm{E}\right)\end{array}$ \\
\hline Altitude above see level & $3-140 \mathrm{~m}$ & $285-550 \mathrm{~m}$ & $460-860 \mathrm{~m}$ \\
\hline Mean annual temperature & $8-8.5^{\circ} \mathrm{C}$ & $6.5-8^{\circ} \mathrm{C}$ & $6-7^{\circ} \mathrm{C}$ \\
\hline Mean annual precipitation & $500-600 \mathrm{~mm}$ & $500-800 \mathrm{~mm}$ & $700-1000 \mathrm{~mm}$ \\
\hline Geological substrate & Quartzitic glacial till & $\begin{array}{l}\text { Triassic limestone } \\
\text { with loess cover }\end{array}$ & Jurassic limestone \\
\hline \multirow[t]{2}{*}{ Main soil types } & Cambisols & Luvisols & Leptosols \\
\hline & Albeluvisols & Stagnosols & Cambisols \\
\hline \multirow[t]{2}{*}{ Main tree species } & Fagus sylvatica $\mathrm{L}$. & Fagus sylvatica L. & Fagus sylvatica L. \\
\hline & $\begin{array}{l}\text { Pinus sylvestris L. } \\
\text { Quercus spp. }\end{array}$ & $\begin{array}{l}\text { Picea abies }(\mathrm{L} .) \text { H. Karst. } \\
\text { Fraxinus excelsior L. }\end{array}$ & Picea abies (L.) H. Karst. \\
\hline
\end{tabular}

Table 2. Stand structural properties and management type of the study plots (dbh is the tree diameter at breast height; data from Schwarz et al., 2014).

\begin{tabular}{llccccc}
\hline Region & Plot ID & Main tree species & Management type & $\begin{array}{c}\text { Stand density } \\
(\mathrm{n} \mathrm{ha}-1)\end{array}$ & $\begin{array}{c}\text { Mean dbh } \\
(\mathrm{cm})\end{array}$ & $\begin{array}{c}\text { Basal area } \\
\left(\mathrm{m}^{2} \mathrm{ha}^{-} 1\right)\end{array}$ \\
\hline Schwäbische Alb & AEW7 & Beech & extensively managed & 200 & 85.2 & 33.3 \\
& AEW8 & Beech & extensively managed & 276 & 56.9 & 40.0 \\
& AEW9 & Beech & extensively managed & 376 & 42.5 & 31.7 \\
\hline Hainich-Dün & HEW1 & Spruce & age-class forest & 276 & 49.4 & 43.0 \\
& HEW2 & Spruce & age-class forest & 660 & 35.9 & 41.3 \\
& HEW3 & Spruce & age-class forest & 651 & 32.2 & 42.7 \\
& HEW10 & Beech & extensively managed & 377 & 50.3 & 34.3 \\
& HEW11 & Beech & extensively managed & 568 & 51.1 & 36.7 \\
& HEW12 & Beech & extensively managed & 326 & 54.9 & 36.5 \\
\hline Schorfheide-Chorin & SEW7 & Beech & extensively managed & 155 & 61.2 & 36.9 \\
& SEW8 & Beech & extensively managed & 154 & 68.0 & 38.3 \\
& SEW9 & Beech & extensively managed & 259 & 52.5 & 43.6 \\
\hline
\end{tabular}

as a sensitive index for the extent of decomposition. The relative aromaticity (in \%) was estimated from the ratio aryl $\mathrm{C} /(\operatorname{aryl} \mathrm{C}+\mathrm{O}$-alkyl $\mathrm{C}+$ alkyl $\mathrm{C})$ as proposed by Hatcher et al. (1981).

\section{Results and discussion}

All spectra shown in Fig. 1 were dominated by the O-alkyl C region $(110-45 \mathrm{ppm})$ and exhibited pronounced signals at ca. 72 ppm, corresponding to secondary carbinol C (i.e. C-2, $\mathrm{C}-3$ and $\mathrm{C}-5$ of pyranoside rings) in cellulose and hemicellulose (Almendros et al., 2000; Keeler et al., 2006; Lemma et al., 2007; Conte et al., 2010). Resonances at ca. 103 ppm were assigned to anomeric $\mathrm{C}$ in carbohydrates (RodríguezMurillo et al., 2011), whereas N-substituted C of amino sugars contributed to the region between 58 and $51 \mathrm{ppm}$ (Knicker and Kögel-Knabner, 1998). In all samples, a maxi- mum peak in the carboxyl $\mathrm{C}$ region at ca. $172 \mathrm{ppm}$ indicated the presence of carboxylic acids, amides and esters originating from compounds such as cutin, proteins and hydrolysable tannins (Lemma et al., 2007).

\subsection{Throughfall}

Unfiltered and filtered TF samples from the beech sites differed remarkably with regard to $\mathrm{C}$ composition. Unfiltered samples revealed clearly decreased signal intensities for the aryl $C$ region (160-110 ppm) that mostly corresponds to lignin systems (ca. 135 ppm, unsubstituted; ca. 145 ppm, heterosubstituted; ca. 153 ppm, ether-linked; Conte et al., 2010; Rodríguez-Murillo et al., 2011) and increased intensities for the alkyl $\mathrm{C}$ region (45 to $-10 \mathrm{ppm}$ ), consistent with higher A / O-A ratio values and lower aromaticity indices for TOM vs. DOM (Tables 3 and 4). 
Table 3. Relative signal intensity (in \%) of chemical shift regions revealed by solid-state ${ }^{13} \mathrm{C}$ NMR spectroscopy (filtered (fil.) and unfiltered (unf.) samples of throughfall (TF), stemflow (SF) and forest floor (FF) leachates; n.a. - not analysed; ALB - Schwäbische Alb; HAI Hainich-Dün; SCH - Schorfheide-Chorin).

\begin{tabular}{|c|c|c|c|c|c|c|c|c|c|c|}
\hline & \multicolumn{2}{|c|}{ Integrated region } & \multicolumn{2}{|c|}{ Chemical shift region } & \multirow{3}{*}{$\begin{array}{r}\text { TF unf. } \\
1.4\end{array}$} & \multirow{3}{*}{$\begin{array}{r}\text { TF fil. } \\
2.8\end{array}$} & \multirow{3}{*}{$\begin{array}{l}\text { SF unf. } \\
2.5\end{array}$} & \multirow{3}{*}{$\begin{array}{r}\text { SF fil. } \\
2.4\end{array}$} & \multirow{3}{*}{$\begin{array}{r}\text { FF unf. } \\
3.1\end{array}$} & \multirow{3}{*}{$\begin{array}{r}\text { FF fil. } \\
2.6\end{array}$} \\
\hline & & & & & & & & & & \\
\hline \multirow{8}{*}{ 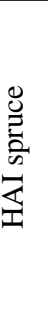 } & 220 & 185 & Carboxyl C & Carbonyl C & & & & & & \\
\hline & 185 & 160 & & Carboxyl C & 9.2 & 9.7 & 10.2 & 10.2 & 12.8 & 12.7 \\
\hline & 160 & 140 & Aryl C & Phenolic C & 4.9 & 5.7 & 5.6 & 5.5 & 6.0 & 5.8 \\
\hline & 140 & 110 & & Aromatic C & 10.3 & 11.5 & 11.5 & 11.1 & 12.8 & 12.2 \\
\hline & 110 & 90 & O-alkyl C & Di-O-alkyl C & 9.0 & 8.6 & 9.7 & 9.6 & 8.7 & 8.2 \\
\hline & 90 & 60 & & Carbohydrate C & 29.3 & 27.4 & 29.9 & 30.4 & 25.3 & 24.8 \\
\hline & 60 & 45 & & Methoxyl C & 10.0 & 9.7 & 9.7 & 9.7 & 10.1 & 9.8 \\
\hline & 45 & -10 & Alkyl C & Aliphatic C & 25.8 & 24.7 & 20.9 & 21.1 & 21.3 & 23.9 \\
\hline \multirow{8}{*}{ 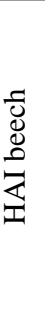 } & 220 & 185 & Carboxyl C & Carbonyl C & 3.9 & 1.5 & 2.4 & 2.1 & 2.4 & 4.4 \\
\hline & 185 & 160 & & Carboxyl C & 10.2 & 8.8 & 11.3 & 11.0 & 13.3 & 13.7 \\
\hline & 160 & 140 & Aryl C & Phenolic C & 5.1 & 9.0 & 5.3 & 4.9 & 7.1 & 6.9 \\
\hline & 140 & 110 & & Aromatic C & 9.7 & 17.1 & 9.9 & 9.1 & 13.7 & 12.9 \\
\hline & 110 & 90 & O-alkyl C & Di-O-alkyl C & 7.4 & 11.7 & 9.7 & 9.3 & 9.3 & 8.2 \\
\hline & 90 & 60 & & Carbohydrate C & 28.3 & 24.5 & 30.8 & 31.3 & 24.2 & 22.6 \\
\hline & 60 & 45 & & Methoxyl C & 8.5 & 8.6 & 9.5 & 9.8 & 10.4 & 9.9 \\
\hline & 45 & -10 & Alkyl C & Aliphatic C & 26.8 & 18.8 & 21.1 & 22.5 & 19.5 & 21.4 \\
\hline \multirow{8}{*}{ 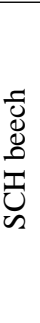 } & 220 & 185 & Carboxyl C & Carbonyl C & 1.4 & 3.6 & 0.6 & 0.8 & 1.6 & 6.7 \\
\hline & 185 & 160 & & Carboxyl C & 9.3 & 10.2 & 9.5 & 10.7 & 9.6 & 11.9 \\
\hline & 160 & 140 & Aryl C & Phenolic C & 7.0 & 10.2 & 3.9 & 5.3 & 6.5 & 6.2 \\
\hline & 140 & 110 & & Aromatic C & 13.3 & 19.0 & 8.2 & 9.7 & 13.4 & 12.0 \\
\hline & 110 & 90 & O-alkyl C & Di-O-alkyl C & 10.2 & 11.9 & 8.2 & 8.8 & 9.9 & 8.1 \\
\hline & 90 & 60 & & Carbohydrate C & 27.0 & 23.5 & 30.6 & 29.4 & 27.5 & 24.0 \\
\hline & 60 & 45 & & Methoxyl C & 9.3 & 7.3 & 10.2 & 10.4 & 9.7 & 9.1 \\
\hline & 45 & -10 & Alkyl C & Aliphatic C & 22.5 & 14.3 & 28.8 & 24.9 & 21.7 & 22.0 \\
\hline \multirow{8}{*}{$\begin{array}{l}\frac{1}{0} \\
8 \\
0 \\
0 \\
0 \\
\frac{1}{4}\end{array}$} & 220 & 185 & Carboxyl C & Carbonyl C & 1.9 & n.a. & n.a. & n.a. & 2.2 & 2.7 \\
\hline & 185 & 160 & & Carboxyl C & 10.1 & n.a. & n.a. & n.a. & 12.2 & 13.2 \\
\hline & 160 & 140 & Aryl C & Phenolic C & 6.9 & n.a. & n.a. & n.a. & 6.1 & 6.3 \\
\hline & 140 & 110 & & Aromatic C & 12.7 & n.a. & n.a. & n.a. & 12.6 & 13.6 \\
\hline & 110 & 90 & O-alkyl C & Di-O-alkyl C & 10.3 & n.a. & n.a. & n.a. & 8.9 & 9.4 \\
\hline & 90 & 60 & & Carbohydrate C & 28.6 & n.a. & n.a. & n.a. & 25.7 & 25.8 \\
\hline & 60 & 45 & & Methoxyl C & 8.7 & n.a. & n.a. & n.a. & 10.4 & 9.7 \\
\hline & 45 & -10 & Alkyl C & Aliphatic C & 20.9 & n.a. & n.a. & n.a. & 21.9 & 19.3 \\
\hline
\end{tabular}

This is likely to point to aliphatic $\mathrm{C}$ from less decomposed organic material accompanied by reduced humification intensity compared with filtered TF samples, where the intensity of the aromatic C region (140-110 ppm) was amplified by $60 \%$ on average. For the O-alkyl C (110-45 ppm) and carboxyl C (220-160 ppm) regions, the trends appeared inconsistent (Table 3, Fig. 1). In essence, DOM in TF under beech was dominated by aryl $\mathrm{C}$ at the expense of alkyl $\mathrm{C}$, resulting in remarkably higher aromaticity index values. A high proportion of aromatic $\mathrm{C}$ in DOM points to increased recalcitrance of DOM towards microbial degradability due to the inhibitory effects of these compounds on enzyme activity (e.g. $\alpha$-amylase, trypsin, lysozyme; Rohn et al., 2002; Marschner and Kalbitz, 2003).
About $30 \%$ of aryl $\mathrm{C}$ was composed of phenolic C (Table 3), partly forming secondary metabolites, which are known to inhibit both the germination and growth of plants, thereby affecting the distribution patterns and composition of understory vegetation of forests (Rice, 1984; Muscolo et al., 2001; Hane et al., 2003). Furthermore, they affect the growth of mycorrhizal fungi (Lindeberg, 1985) and inhibit feeding by various fungi (Alfredsen et al., 2008) and potential herbivores (Dübeler et al., 1997; Petrakis et al., 2011). In their review, Wardle et al. (1998) concluded that the effect of plants with allelopathic potential on other organisms may ultimately result not only in net change on the population level (e.g. plant-plant interference) but in net change in ecosystem processes and functions (e.g. herbivory, decomposition and 


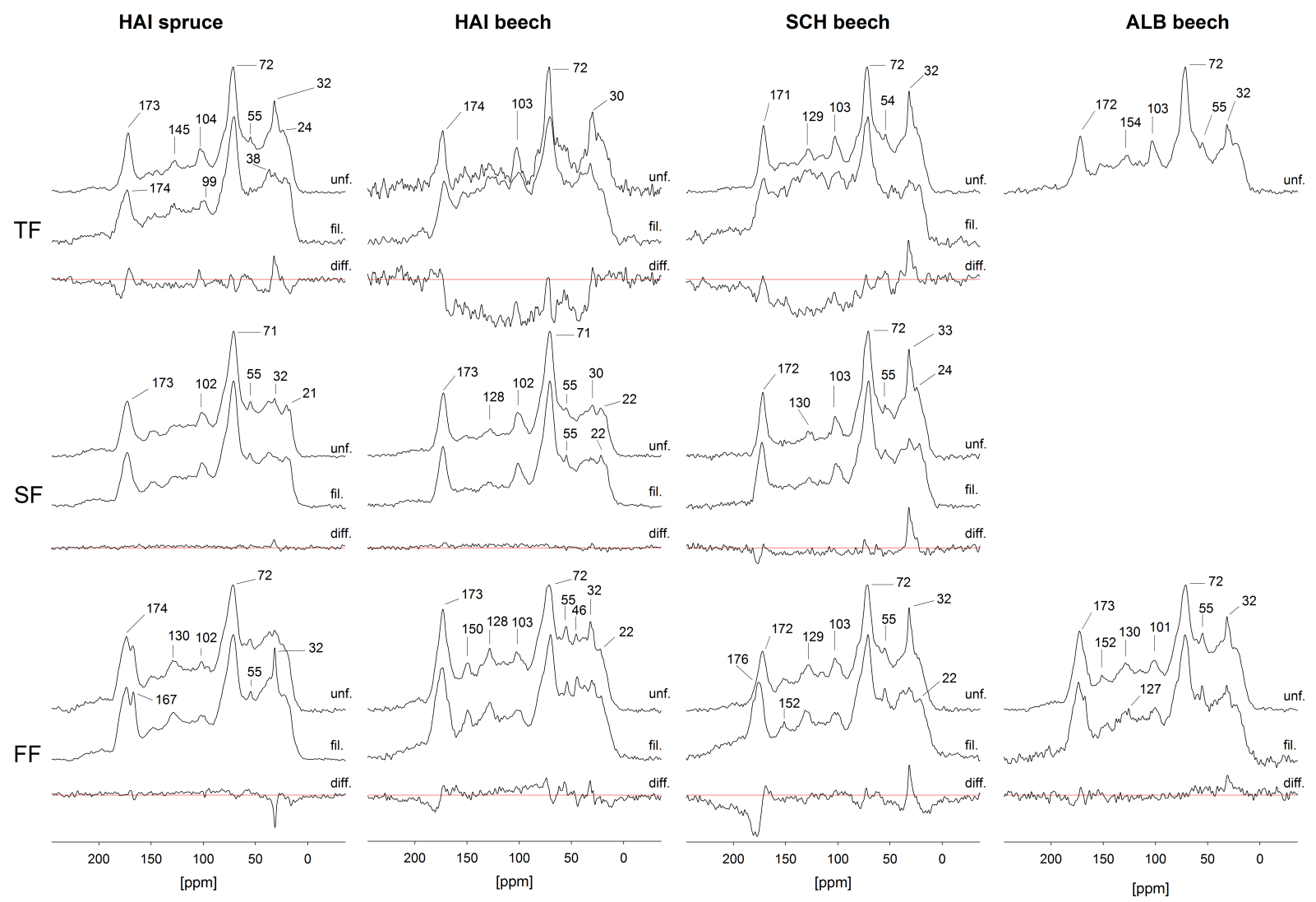

Figure 1. Solid-state CPMAS ${ }^{13} \mathrm{C}$ NMR spectra obtained from filtered (fil.) and unfiltered (unf.) forest ecosystem water samples as well as calculated difference spectra (diff.) of both fractions; TF stands for throughfall, SF for stemflow, FF for forest floor leachate, ALB for Schwäbische Alb, HAI for Hainich-Dün and SCH for Schorfheide-Chorin; red lines indicate zero level within difference spectra.

nutrient mineralization), which may be important in shaping plant community structure in the long term.

In comparison with beech, the analysis of ${ }^{13} \mathrm{C}$ chemical shift regions of the unfiltered and filtered $\mathrm{TF}$ samples from the HAI spruce forests indicated only minor differences in C fraction composition (Table 3, Fig. 1). In this context, the $\mathrm{C}$ of the unfiltered TF samples exhibited slightly higher relative intensities for aliphatic $\mathrm{C}$ ( 45 to $-10 \mathrm{ppm}$ ) and carbohydrate $\mathrm{C}$ (90-60 ppm) and lower relative intensities for aryl C (160-110 ppm) and carboxyl C (220-160 ppm) compared with filtered samples. This aspect was mirrored by the lower aromaticity index of the unfiltered samples (17.0) compared with the filtered samples (19.6; Table 4).

The less pronounced differences in DOM and TOM composition under spruce compared to beech appear to be substantiated in differing interspecific canopy metrics. Spruce trees in Germany exhibit a denser foliage and higher leaf area index of $20.5 \mathrm{~m}^{2} \mathrm{~m}^{-2}$ compared with $6.5 \mathrm{~m}^{2} \mathrm{~m}^{-2}$ for beech, as well as greater needle surface roughness and greater leaf longevity (Rothe et al., 2002). Consequently, spruce canopies provide a higher filtering capacity for airborne compounds and a higher accumulation rate than beech canopies. Additionally, spruce canopies exhibit higher rainfall interception rate values of 30-40\% compared with $17-20 \%$ for beech canopies (Rothe et al., 2002). This might lead to longer periods of water availability, longer contact time for rainwater and needle surfaces and substrate availability, and hence more stable environmental conditions within the phyllosphere, likely promoting the microbial decomposition of TOM to DOM and hence diminishing structural differences.

Compared to the HAI spruce sites, Sanderman et al. (2008) found similar distributions in the relative intensities of chemical shift regions for DOM in TF of a nearly 100-yearold mixed Redwood and Douglas fir stand in California. In contrast, Fröberg et al. (2003) reported differing intensities for DOM in TF from a 35-year-old Norway spruce stand in southern Sweden, with lower carbonyl C and aryl $\mathrm{C}$ but higher O-alkyl $\mathrm{C}$ contents, even resulting in a lower A / O-A ratio (0.42) and aromaticity index (12.24\%). To our knowledge, there are no comparable studies of beech-derived TF samples or of SF samples in general. The diverging results from Sweden are likely due to the younger stand age or differences in stand structure and climate. 
Table 4. Alkyl C/O-alkyl C (A/O-A) ratios and aromaticity (in \%) calculated from chemical shift regions revealed by solidstate ${ }^{13} \mathrm{C}$ NMR spectroscopy of filtered (fil.) and unfiltered (unf.) samples of throughfall (TF), stemflow (SF) and forest floor (FF) leachates; n.a. - not analysed; ALB - Schwäbische Alb; HAI Hainich-Dün; SCH - Schorfheide-Chorin.

\begin{tabular}{|c|c|c|c|}
\hline & Sample & A / O-A ratio & $\begin{array}{c}\text { Aromaticity } \\
(\%)\end{array}$ \\
\hline \multirow{6}{*}{ 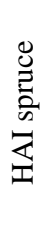 } & TF unf. & 0.53 & 17.0 \\
\hline & TF fil. & 0.54 & 19.6 \\
\hline & SF unf. & 0.42 & 19.7 \\
\hline & SF fil. & 0.42 & 19.0 \\
\hline & FF unf. & 0.48 & 22.4 \\
\hline & FF fil. & 0.56 & 21.2 \\
\hline \multirow{6}{*}{ 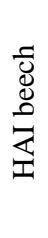 } & TF unf. & 0.61 & 17.3 \\
\hline & TF fil. & 0.42 & 29.1 \\
\hline & SF unf. & 0.42 & 17.7 \\
\hline & SF fil. & 0.45 & 16.1 \\
\hline & FF unf. & 0.44 & 24.7 \\
\hline & FF fil. & 0.53 & 24.2 \\
\hline \multirow{6}{*}{ 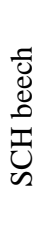 } & TF unf. & 0.49 & 22.7 \\
\hline & TF fil. & 0.33 & 33.9 \\
\hline & SF unf. & 0.59 & 13.5 \\
\hline & SF fil. & 0.51 & 16.9 \\
\hline & FF unf. & 0.46 & 22.5 \\
\hline & FF fil. & 0.53 & 22.4 \\
\hline \multirow{6}{*}{ 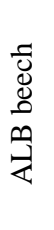 } & TF unf. & 0.44 & 22.3 \\
\hline & TF fil. & n.a. & n.a. \\
\hline & SF unf. & n.a. & n.a. \\
\hline & SF fil. & n.a. & n.a. \\
\hline & FF unf. & 0.49 & 21.8 \\
\hline & FF fil. & 0.43 & 23.7 \\
\hline
\end{tabular}

\subsection{Stemflow}

As illustrated by difference spectra, unfiltered and filtered SF samples under beech as well as under spruce showed similar distributions and signal intensities (Fig.1). However, the difference spectra from $\mathrm{SCH}$ samples exhibited pronounced peaks at ca. $30 \mathrm{ppm}$ within the alkyl $\mathrm{C}$ region, which can be assigned to methylenes in fatty acyl chains (Lundberg et al., 2001). These peaks point to a local event at the SCH beech sites and might be derived from excretions of canopy insects such as the beech woolly aphid (Phyllaphis fagi L.) or other leaf-sucking insects. Herbivorous insect species are known to temporarily occur in mass infestations and then alter the input fluxes, especially of POM, by, e.g., green leaf litter, wax wool excretion and cell tissue (Stadler et al., 2001; le Mellec and Michalzik, 2008). In this context, Greenway et al. (1974) reported on the composition of triglycerides found in cornicle secretions from a range of aphid families, including $P$. fagi. Additionally, Stanley-Samuelson et al. (1988) reviewed the formation of fatty acids in cuticular secretion components of other insect orders.

\subsection{Forest floor leachates}

Regarding FF leachates under beech, unfiltered samples of two (HAI and $\mathrm{SCH}$ ) out of the three exploratories exhibited higher intensities within the O-alkyl C region (110-45 ppm) and lower signals in the carboxyl $\mathrm{C}$ region $(220-160 \mathrm{ppm})$ compared with the filtered samples (Fig. 1). While the aromaticity index among the FF leachate fractions was similar, with values around 22 and $24 \%$, the A / O-A ratio values were lower for the TOM than the DOM fractions (Table 4). This trend was observed for FF leachates from all the sites and for both tree species, except for the ALB beech sites. Here, the two fractions of FF leachate revealed only minor differences in $\mathrm{C}$ composition and $\mathrm{A} / \mathrm{O}-\mathrm{A}$ ratio. Again, no corresponding data for beech stands were available in the literature, but for a spruce forest site in southern Sweden, Fröberg et al. (2003) reported similar signal intensities from solid-state ${ }^{13} \mathrm{C}$ NMR spectra of Oa layer solutions. In contrast, ${ }^{13} \mathrm{C}$ NMR data for $\mathrm{FF}$ leachates of a Californian mixed Redwood stand reported by Sanderman et al. (2008) exhibited lower intensities for alkyl $\mathrm{C}$ and remarkably higher intensities for the aromatic $\mathrm{C}$ region, resulting in an approximately halved A / O-A ratio compared with our spruce sites. We assume that the diverging sampling period and season along with different climatic and hydrological conditions (Mediterranean vs. temperate) are responsible for the differences in DOM composition. In this context, enhanced hydrological flux generation (e.g. throughout rainy seasons) was shown to increase the aromaticity of DOM by the intensified degradation of soluble lignin compounds as observed by Guggenberger et al. (1994) and Levia et al. (2012).

In summary, the compositional differences between DOM and TOM at the beech sites diminished in the following order $\mathrm{TF}>\mathrm{SF} \approx \mathrm{FF}$ leachates. This might be related to longer stemflow-bark contact time due to the bark microrelief, less changing environmental conditions, and better substrate availability on the tree stem (Levia et al., 2012) and stagnant water on the litter surfaces of the forest floor favouring the degradation of canopy-derived OM by the soil biota and epiphytic microorganisms that level out differences in the composition and quality between the two size fractions.

The differing composition of DOM under beech vs. spruce might be substantiated in differences in tree species-specific structural effects, leaching characteristics or differences in the microbial community of the tree species' phyllosphere and cortisphere (Guggenberger and Zech, 1994; Stadler and Müller, 2000).

The discussion generally lacks comparable data on TOM composition as, to the best of our knowledge, there are no studies available on solid-state ${ }^{13} \mathrm{C}$-NMR-spectroscopyderived TOM characteristics in TF, SF and FF leachate samples under beech or other tree species. 


\section{Conclusions}

Structural data derived from solid-state ${ }^{13} \mathrm{C}$ NMR analysis confirmed pronounced differences between filtered and unfiltered beech TF samples. The compositional differences between DOM and TOM diminished from TF to SF and FF leachates. This might be due to increased contact time and intensified microbial activity levelling out the compositional differences between the two OM fractions. Since differences in the structural composition of DOM and TOM in TF and SF were less pronounced under spruce than under beech, we suspect a tree-species-related effect on the origin of OM composition and resulting properties such as recalcitrance and allelopathic potential. To consolidate our findings on treespecies-specific differences in the amount and functionality of OM in TF samples and ecological implications, research has to be extended spatially and to further tree species. 


\section{Appendix A}

Table A1. Abbreviations

\begin{tabular}{ll}
\hline${ }^{13}$ C CPMAS NMR & $\begin{array}{l}\text { Carbon-13 cross-polarization and magic-angle spinning nuclear } \\
\text { magnetic resonance }\end{array}$ \\
ALB & Schwäbische Alb exploratory \\
A / O-A & Alkyl C to O-alkyl C ratio \\
BP & Bulk precipitation \\
DOM & Dissolved organic matter \\
FF & Forest floor \\
HAI & Hainich-Dün exploratory \\
OM & Organic matter \\
PE & Polyethylene \\
POM & Particulate organic matter \\
SCH & Schorfheide-Chorin exploratory \\
SF & Stemflow \\
TF & Throughfall \\
TOM & Total organic matter \\
\hline
\end{tabular}


Acknowledgements. We thank the managers of the three exploratories - Kirsten Reichel-Jung, Swen Renner, Katrin Hartwich, Sonja Gockel, Kerstin Wiesner and Martin Gorke - for their work in maintaining the plot and project infrastructure, Christiane Fischer and Simone Pfeiffer for giving support through the central office, Michael Owonibi for managing the central database, and Markus Fischer, Eduard Linsenmair, Dominik Hessenmöller, Jens Nieschulze, Daniel Prati, Ingo Schöning, François Buscot, Ernst-Detlef Schulze, Wolfgang W. Weisser, and the late Elisabeth Kalko for their role in setting up the Biodiversity Exploratories project.

We also thank M. Steffens for performing the NMR measurements, S. Tetzlaff and K. Pfeiffer for technical assistance, and D.F. Levia for constructive comments on the manuscript.

The work has been funded by the DFG Priority Program 1374 "Infrastructure-Biodiversity-Exploratories". Field work permits were issued by the responsible state environmental offices of Brandenburg, Thüringen and Baden-Württemberg (according to $\S 72$ BbgNatSchG).

Edited by: K. Küsel

\section{References}

Alfredsen, G., Solheim, H., and Slimestad, R.: Antifungal effect of bark extracts from some European tree species, European J. Forest Res.-Jpn., 127, 387-393, 2008.

Almendros, G., Dorado, J., González-Vila, F. J., Blanco, M., and Lankes, U.: ${ }^{13} \mathrm{C}$ NMR assessment of decomposition patterns during composting of forest and shrub biomass, Soil Biol. Biochem., 32, 793-804, 2000.

Andrews, J. H. and Harris, R. F.: The ecology and biogeography of microorganisms on plant surfaces, Annu. Rev. Phytopathol., 38, 145-180, 2000.

Balaria, A., Johnson, C. E., and Xu, Z.: Molecular-scale characterization of hot-water-extractable organic matter in organic horizons of a forest soil, Soil Sci. Soc. Am. J., 73, 812-821, 2009.

Baldock, J., Oades, J., Nelson, P., Skene, T., Golchin, A., and Clarke, P.: Assessing the extent of decomposition of natural organic materials using solid-state ${ }^{13} \mathrm{C}$ NMR spectroscopy, Aust. J. Soil Res., 35, 1061-1084, 1997.

Baldock, J. A., Masiello, C., Gelinas, Y., and Hedges, J.: Cycling and composition of organic matter in terrestrial and marine ecosystems, Mar. Chem., 92, 39-64, 2004.

Bussotti, F., Gravano, E., Grossoni, P. and Tani, C.: Occurrence of tannins in leaves of beech trees (Fagus sylvatica) along an ecological gradient, detected by histochemical and ultrastructural analyses, New Phytol., 138, 469-479, 1998.

Carlisle, A., Brown, A., and White, E.: The organic matter and nutrient elements in the precipitation beneath a sessile oak (Quercus petraea) canopy, J. Ecol., 54, 87-98, 1966.

Conte, P., De Pasquale, C., Novotny, E. H., Caponetto, G., Laudicina, V. A., Ciofalo, M., Panno, M., Palazzolo, E., Badalucco, L., and Alonzo, G.: CPMAS ${ }^{13} \mathrm{C}$ NMR characterization of leaves and litters from the reafforestated area of Mustigarufi in Sicily (Italy), Open Magnetic Resonance Journal, 3, 89-95, 2010.

Currie, W. S., Aber, J. D., McDowell, W. H., Boone, R. D., and Magill, A. H.: Vertical transport of dissolved organic $\mathrm{C}$ and $\mathrm{N}$ under long-term $\mathrm{N}$ amendments in pine and hardwood forests, Biogeochemistry, 35, 471-505, 1996.

Dübeler, A., Voltmer, G., Gora, V., Lunderstädt, J., and Zeeck, A.: Phenols from Fagus sylvatica and their role in defence against Cryptococcus fagisuga, Phytochemistry, 45, 51-57, 1997.

Finzi, A. C., Canham, C. D., and Van Breemen, N.: Canopy treesoil interactions within temperate forests: species effects on $\mathrm{pH}$ and cations, Ecol. Appl., 8, 447-454, 1998.

Fischer, M., Bossdorf, O., Gockel, S., Hänsel, F., Hemp, A., Hessenmöller, D., Korte, G., Nieschulze, J., Pfeiffer, S., Prati, D., Renner, S., Schöning, I., Schumacher, U., Wells, K., Buscot, F., Kalko, E., Linsenmair, K., Schulze, E., and Weisser, W.: Implementing large-scale and long-term functional biodiversity research: the biodiversity exploratories, Basic Appl. Ecol., 11, 473-485, 2010.

Fontaine, S., Bardoux, G., Abbadie, L., and Mariotti, A.: Carbon input to soil may decrease soil carbon content, Ecol. Lett., 7, 314320, 2004.

Fröberg, M., Berggren, D., Bergkvist, B., Bryant, C., and Knicker, H.: Contributions of Oi, Oe and Oa horizons to dissolved organic matter in forest floor leachates, Geoderma, 113, 311-322, 2003.

Fröberg, M., Berggren, D., Bergkvist, B., Bryant, C., and Mulder, J.: Concentration and fluxes of dissolved organic carbon (DOC) in three Norway spruce stands along a climatic gradient in Sweden, Biogeochemistry, 77, 1-23, 2006.

Gersper, P. L. and Holowaychuk, N.: Some effects of stem flow from forest canopy trees on chemical properties of soils, Ecology, 52, 691-702, 1971.

Greenway, A., Griffiths, D., Furk, C., and Prior, R.: Composition of triglycerides from aphids of six different families and from different seasonal forms of Aphis evonymi, J. Insect Physiol., 20, 2423-2431, 1974.

Guggenberger G. and Zech, W.: Composition and dynamics of dissolved carbohydrates and lignin-degradation products in two coniferous forests, NE Bavaria, Germany, Soil Biol. Biochem., 26, 19-27, 1994.

Guggenberger, G., Zech, W., and Schulten, H.-R.: Formation and mobilization pathways of dissolved organic matter: evidence from chemical structural studies of organic matter fractions in acid forest floor solutions, Org. Geochem., 21, 51-66, 1994.

Hane, E. N., Hamburg, S. P., Barber, A. L., and Plaut, J. A.: Phytotoxicity of American beech leaf leachate to sugar maple seedlings in a greenhouse experiment, Can. J. Forest Res., 33, 814-821, 2003.

Hatcher, P. G., Schnitzer, M., Dennis, L. W., and Maciel, G. E.: Aromaticity of humic substances in soils, Soil Sci. Soc. Am. J., 45, 1089-1094, 1981.

Helfrich, M., Ludwig, B., Buurman, P., and Flessa, H.: Effect of land use on the composition of soil organic matter in density and aggregate fractions as revealed by solid-state ${ }^{13} \mathrm{C}$ NMR spectroscopy, Geoderma, 136, 331-341, 2006.

IUSS Working group WRB: Guidelines for Soil Description, 4th edn., Food and Agricultural Organisation of the United Nations, Rome, Italy, 97 pp., 2006.

Keeler, C., Kelly, E. F., and Maciel, G. E.: Chemical-structural information from solid-state ${ }^{13} \mathrm{C}$ NMR studies of a suite of humic materials from a lower montane forest soil, Colorado, USA, Geoderma, 130, 124-140, 2006. 
Kindler, R., Siemens, J., Kaiser, K., Walmsley, D., Bernhofer, C., Buchmann, N., Cellier, P., Eugster, W., Gleixner, G., Grünwald, T., Heim, A., Ibrom, A., Jones, S., Jones, M., Klumpp, K., Kutsch, W., Larsen, K., Lehuger, S., Loubet, B., McKenzie, R., Moors, E., Osborne, B., Pilegaard, K., Rebmann, C., Saunders, M., Schmidt, M., Schrumpf, M., Seyfferth, J., Skiba, U., Soussana, J.-F., Sutton, M., Tefs, C., Vowinckel, B., Zeeman, M., and Kaupenjohann, M.: Dissolved carbon leaching from soil is a crucial component of the net ecosystem carbon balance, Glob. Change Biol., 17, 1167-1185, 2011.

Knicker, H. and Kögel-Knabner, I.: Soil organic nitrogen formation examined by means of NMR spectroscopy, in: NitrogenContaining Macromolecules in the Bio- and Geosphere, edited by: Stankiewicz, B. and van Bergen, P., ACS Symposium Series, American Chemical Society, Washington DC, 339-356, 1998.

Knicker, H., González-Vila, F. J., Polvillo, O., González, J. A., and Almendros, G.: Fire-induced transformation of C- and N-forms in different organic soil fractions from a dystric cambisol under a Mediterranean pine forest Pinus pinaster, Soil Biol. Biochem., 37, 701-718, 2005.

Lamersdorf, N. and Blank, K.: Evaluation of fine material input with throughfall for a spruce forest in Solling, FRG, by means of a roof construction, in: Ecosystem Manipulation Experiments: Scientific Approaches, Experimental Design and Relevant Results, edited by: Jenkings, A., Ferrier, R., and Kirby, C., no. 23 in Ecosystem Research Report, Commission of the European Communities, Office for Official Publications of the European Communities, Brussels, 168-170, 1995.

Lankes, U., Lüdemann, H.-D., and Frimmel, F. H.: Search for basic relationships between "molecular size" and "chemical structure" of aquatic natural organic matter - answers from ${ }^{13} \mathrm{C}$ and ${ }^{15} \mathrm{~N}$ CPMAS NMR spectroscopy, Water Res., 42, 1051-1060, 2008.

Leinweber, P., Schulten, H.-R., and Körschens, M.: Hot water extracted organic matter: chemical composition and temporal variations in a long-term field experiment, Biol. Fert. Soils, 20, 17-23, 1995.

Lemma, B., Nilsson, I., Kleja, D. B., Olsson, M., and Knicker, H.: Decomposition and substrate quality of leaf litters and fine roots from three exotic plantations and a native forest in the southwestern highlands of Ethiopia, Soil Biol. Biochem., 39, 2317-2328, 2007.

le Mellec, A. and Michalzik, B.: Impact of a pine lappet (Dendrolimus pini) mass outbreak on $\mathrm{C}$ and $\mathrm{N}$ fluxes to the forest floor and soil microbial properties in a Scots pine forest in Germany, Can. J. Forest Res., 38, 1829-1841, 2008.

le Mellec, A., Habermann, M., and Michalzik, B.: Canopy herbivory altering $\mathrm{C}$ to $\mathrm{N}$ ratios and soil input patterns of different organic matter fractions in a Scots pine forest, Plant Soil, 325, 255-262, 2009.

le Mellec, A., Meesenburg, H., and Michalzik, B.: The importance of canopy-derived dissolved and particulate organic matter (DOM and POM) - comparing throughfall solution from broadleaved and coniferous forests, Ann. For. Sci., 67, 411 pp., 2010.

Levia, D. F. and Frost, E. E.: Variability of throughfall volume and solute inputs in wooded ecosystems, Prog. Phys. Geog., 30, 605632, 2006

Levia, D. F., Van Stan, J. T., Siegert, C., M., Inamdar, S. P., Mitchell, M. J.,Mage, S. .M, and McHale, P. J.: Atmospheric deposition and corresponding variability of stemflow chemistry across temporal scales in a mid-Atlantic broadleaved deciduous forest, Atmos. Environ., 45, 3046-3054, 2011.

Levia, D. F., Van Stan, II, J. T., Inamdar, S. P., Jarvis, M. T., Mitchell, M. J., Mage, S. M., Scheick, C. E., and McHale, P. J.: Stemflow and dissolved organic carbon cycling: temporal variability in concentration, flux, and UV-Vis spectral metrics in a temperate broadleaved deciduous forest in the eastern United States, Can. J. Forest Res., 42, 207-216, 2012.

Levia, D. F., Michalzik, B., Bischoff, S., Näthe, K., Legates, D. R., Gruselle, M.-C., and Richter, S.: Measurement and modeling of diameter distributions of particulate matter in terrestrial solutions, Geophys. Res. Lett., 40, 1317-1321, 2013.

Likens, G. E., Edgerton, E. S., and Galloway, J. N.: The composition and deposition of organic carbon in precipitation, Tellus B, 35 , 16-24, 1983.

Lindeberg, G.: Stimulation of some litter-decomposing basidiomycetes by shikimic acid, Physiol. Plantarum, 65, 9-14, 1985.

Lundberg, P., Ekblad, A., and Nilsson, M.: ${ }^{13}$ C NMR spectroscopy studies of forest soil microbial activity: glucose uptake and fatty acid biosynthesis, Soil Biol. Biochem., 33, 621-632, 2001.

Mämmelä, P.: Phenolics in selected European hardwood species by liquid chromatography-electrospray ionisation mass spectrometry, Analyst, 126, 1535-1538, 2001.

Marschner, B. and Kalbitz, K.: Controls of bioavailability and biodegradability of dissolved organic matter in soils, Geoderma, 113, 211-235, 2003.

McKnight, D. M., Harnish, R., Wershaw, R. L., Baron, J. S., and Schiff, S.: Chemical characteristics of particulate, colloidal, and dissolved organic material in Loch Vale Watershed, Rocky Mountain National Park, Biogeochemistry, 36, 99-124, 1997.

Mercier, J. and Lindow, S.: Role of leaf surface sugars in colonization of plants by bacterial epiphytes, Appl. Environ. Microb., 66, 369-374, 2000.

Michalzik, B. and Matzner, E.: Dynamics of dissolved organic nitrogen and carbon in a Central European Norway spruce ecosystem, Eur. J. Soil Sci., 50, 579-590, 1999.

Michalzik, B. and Stadler, B.: Importance of canopy herbivores to dissolved and particulate organic matter fluxes to the forest floor, Geoderma, 127, 227-236, 2005.

Muscolo, A., Panuccio, M., and Sidari, M.: The effect of phenols on respiratory enzymes in seed germination, Plant Growth Regul., 35, 31-35, 2001.

Nicolai, V.: The bark of trees: thermal properties, microclimate and fauna, Oecologia, 69, 148-160, 1986.

Pérez-Harguindeguy, N., Díaz, S., Cornelissen, J. H. C., Vendramini, F., Cabido, M., and Castellanos, A.: Chemistry and toughness predict leaf litter decomposition rates over a wide spectrum of functional types and taxa in central Argentina, Plant Soil, 218, 21-30, 2000.

Petrakis, P. V., Spanos, K., Feest, A., and Daskalakou, E.: Phenols in leaves and bark of Fagus sylvatica as determinants of insect occurrences, Int. J. Mol. Sci., 12, 2769-2782, 2011.

Qualls, R. G. and Haines, B. L.: Geochemistry of dissolved organic nutrients in water percolating through a forest ecosystem, Soil Sci. Soc. Am. J., 55, 1112-1123, 1991.

Qualls, R. G., Haines, B. L., and Swank, W. T.: Fluxes of dissolved organic nutrients and humic substances in a deciduous forest, Ecology, 72, 254-266, 1991. 
Rice, E. L.: Allelopathy, Academic Press, New York, 368 pp., 1984.

Rodríguez-Murillo, J. C., Almendros, G., and Knicker, H.: Wetland soil organic matter composition in a Mediterranean semiarid wetland (Las Tablas de Daimiel, Central Spain): insight into different carbon sequestration pathways, Org. Geochem., 42, 762-773, 2011.

Rohn, S., Rawel, H. M., and Kroll, J.: Inhibitory effects of plant phenols on the activity of selected enzymes, J. Agr. Food Chem., 50, 3566-3571, 2002.

Rothe, A., Huber, C., Kreutzer, K., and Weis, W.: Deposition and soil leaching in stands of Norway spruce and European beech: results from the Höglwald research in comparison with other $\mathrm{Eu}-$ ropean case studies, Plant Soil, 240, 33-45, 2002.

Sanderman, J., Baldock, J. A., and Amundson, R.: Dissolved organic carbon chemistry and dynamics in contrasting forest and grassland soils, Biogeochemistry, 89, 181-198, 2008.

Schnitzer, M. and Khan, S. U.: Humic Substances in the Environment, Marcel Dekker, New York, 327 pp., 1972.

Schumacher, M., Christl, I., Vogt, R. D., Barmettler, K., Jacobsen, C., and Kretzschmar, R.: Chemical composition of aquatic dissolved organic matter in five boreal forest catchments sampled in spring and fall seasons, Biogeochemistry, 80, 263-275, 2006.

Schwarz, M. T., Bischoff, S., Blaser, S., Boch, S., Schmitt, B., Thieme, L., Fischer, M., Michalzik, B., Schulze, E. D., Siemens, J., and Wilcke, W.: More efficient aboveground nitrogen use in more diverse Central European forest canopies, Forest Ecol. Manag., 313, 274-282, 2014.

Sollins, P., Grier, C., McCorison, F., Cromack Jr., K., Fogel, R., and Fredriksen, R.: The internal element cycles of an old-growth Douglas-fir ecosystem in western Oregon, Ecol. Monogr., 50, 261-285, 1980.
Stadler, B. and Müller, T.: Effects of aphids and moth caterpillars on epiphytic microorganisms in canopies of forest trees, Can. J. Forest Res., 30, 631-638, 2000.

Stadler, B., Solinger, S., and Michalzik, B.: Insect herbivores and the nutrient flow from the canopy to the soil in coniferous and deciduous forests, Oecologia, 126, 104-113, 2001.

Stadler, B., Müller, T., and Orwig, D.: The ecology of energy and nutrient fluxes in hemlock forests invaded by hemlock woolly adelgid, Ecology, 87, 1792-1804, 2006.

Stanley-Samuelson, D. W., Jurenka, R. A., Cripps, C., Blomquist, G. J., and de Renobales, M.: Fatty acids in insects: composition, metabolism, and biological significance, Arch. Insect Biochem., 9, 1-33, 1988.

Van Stan, J. T., Levia, D. F., Inamdar, S. P., Lepori-Bui, M., and Mitchell, M.: The effects of phenoseason and storm characteristics on throughfall solute washoff and leaching dynamics from a temperate deciduous forest canopy, Sci. Total Environ., 430, 48-58, 2012.

Wardle, D. A., Nilsson, M.-C., Gallet, C., and Zackrisson, O.: An ecosystem-level perspective of allelopathy, Biol. Rev., 73, 305319, 1998.

Weissen, F. and Van Praag, H. J.: Root growth inhibition effects of holorganic moder humus layer under spruce (Picea abies Karst.) and beech (Fagus sylvatica L.), Plant Soil, 135, 167-174, 1991.

Wyse, S. V. and Burns, B. R.: Do host bark traits influence trunk epiphyte communities?, New Zeal. J. Ecol., 35, 296-301, 2011. 